\title{
Investment in Microfinance Equity: Risk, Return, and Diversification Benefits
}

\section{Marie Brière and Ariane Szafarz}

This paper draws a global picture of worldwide microfinance equity. Taking full advantage of daily quoted prices of microfinance stocks from their issuance, we construct microfinance country equity indices and an international global microfinance index. We analyze changes in these indices, assessed in reference to comparable indices for the financial sector and also to national indices. Our findings show that microfinance has been closely correlated with the financial sector since 2003. In terms of risk exposure, estimates of the Capital Asset Pricing Model demonstrate that microfinance shares exhibit higher market beta than those of conventional financial institutions and have equivalent currency exposure.

JEL Classifications: G11, G15, O16, C58, G21

Keywords: Microfinance, portfolio management, equity, emerging markets

\section{CEB Working Paper $N^{\circ} 11 / 050$}

October 2011 


\title{
Investment in Microfinance Equity:
}

\section{Risk, Return, and Diversification Benefits}

\author{
Marie Brière \\ Amundi and Université Libre de Bruxelles (ULB), SBS-EM, CEB \\ 90, bd. Pasteur \\ 75015 Paris \\ France \\ marie.briere@amundi.com \\ Ariane Szafarz* \\ Université Libre de Bruxelles (ULB), SBS-EM, CEB, and CERMi \\ 50, av. F.D. Roosevelt, CP114/03 \\ 1050 Brussels \\ Belgium \\ aszafarz@ulb.ac.be
}

October 2011

Keywords: Microfinance, portfolio management, equity, emerging markets.

JEL codes: G11, G15, O16, C58, G21

* Corresponding author 


\begin{abstract}
This paper draws a global picture of worldwide microfinance equity. Taking full advantage of daily quoted prices of microfinance stocks from their issuance, we construct microfinance country equity indices and an international global microfinance index. We analyze changes in these indices, assessed in reference to comparable indices for the financial sector and also to national indices. Our findings show that microfinance has been closely correlated with the financial sector since 2003. In terms of risk exposure, estimates of the Capital Asset Pricing Model demonstrate that microfinance shares exhibit higher market beta than those of conventional financial institutions and have equivalent currency exposure.
\end{abstract}


The microfinance industry offers attractive opportunities to investors seeking to participate in alleviating poverty in developing countries. Furthermore, microfinance is often perceived as different from conventional finance. It is thought to be riskier because borrowers generally have no collateral and little or no credit history on which to base a precise assessment of their credit risk. Despite this, investing in microfinance is also viewed as a way of diversifying from international markets in general and the conventional financial sector in particular (Gonzalez, 2007; Krauss and Walter, 2009; Di Bella, 2011; Galema et al, 2011). This diversification effect stems from the special nature of microfinance institutions, with a business driven by a double bottom line, and the fact that they are less leveraged than traditional financial institutions.

However, microfinance has changed dramatically during the last decade, moving from a universe of donor-financed NGOs towards a widely disparate industry (Mersland, 2009), including a growing number of commercial banks. Simultaneously, socially responsible investments have gained momentum on financial markets. This paper examines whether the diversification benefits of microfinance investment have survived the recent evolution of the industry. We therefore assess the impact of microfinance equity on globally diversified portfolios by using the classical tools of portfolio analysis. For that purpose, we construct original microfinance country indices, analyze their movements, and assess them in reference to comparable indices for the financial sector and to national indices. International equity indices are also taken into consideration. ${ }^{1}$

\footnotetext{
${ }^{1}$ In 2003 J.P. Morgan created the Low-Income Finance Institutions (LIFIs) index, including not only listed MIFs but also other financial institutions (see J.P. Morgan, 2009). Wall's Street Advisor Services (WSAS) has also released a set of benchmarks for investments in MFIs, the WSAS MFI Shareholder Value Indices, computed from book values (see http://www.wallsstreetadvisorservices.com/). By contrast, our indices are based on market prices only.
} 
Our findings show that although the microfinance sector has definitely moved closer to conventional finance, the risk-return trade-off has also changed. ${ }^{2}$ Microfinance equity is now less risky than before, but it is also much more closely correlated with the financial sector, and it yields fewer diversification benefits. In this respect, we show in particular microfinance can reasonably be considered as part of the financial sector.

Two types of public investments in microfinance are currently available: Microfinance Investment Vehicles (MIVs) ${ }^{3}$ and listed equity of Microfinance Institutions (MFIs). For reasons of data availability, this paper concentrates on listed MFIs. Arguably, microfinance equity is not representative of the whole sector. ${ }^{4}$ However, while restricted to a relatively small number of assets, microfinance equity has the considerable advantage over MIVs of being publicly priced on stock exchanges on a daily basis. This makes it more transparent and allows for deeper financial analysis. Conversely, MIVs invest in several MFIs mainly through loans, but the content of their portfolios is often opaque, ${ }^{5}$ making it difficult for outsiders to assess the actual level of risk.

The microfinance sector has experienced successful initial public offerings (IPOs) such as the highly publicized IPO of Banco Compartamos in Mexico in 2007. These IPOs have nevertheless been criticized by influential players, including Nobel Prize winner Muhammad Yunus, who views the Compartamos IPO as mission drift $^{6}$ that compromises the reputation of

\footnotetext{
${ }^{2}$ This paper examines whether this assertion holds true for investors who are seeking financial returns only. Alternatively, financial and social returns can be combined (see Drut, 2010; Dorfleitner et al., 2011).

${ }^{3}$ See e.g. Matthäus-Maier and von Pischke (2006).

${ }^{4}$ In particular, many MFIs still rely on subsidies for reaching financial sustainability (Hudon, 2010; Nawak, 2010; Hudon and Traca, 2011).

${ }^{5}$ The authors - and colleagues from other universities - have tried for years to obtain data on MIVs with little success. Regarding transparency, MIVs tend to adopt an attitude comparable to that of hedge funds.

${ }^{6}$ The microfinance mission drift stems from the double bottom-line (social and financial) embodied by the MFIs. An MFI is said mission-drifted when it sacrifices its social mission (typically, poverty alleviation and/or women empowerment) for financial purposes (see, e.g., McIntosh and Wydick, 2005; Copestake, 2007; Ghosh and Van Tassel, 2008; Mersland and Strøm, 2010; Armendariz and Szafarz, 2011).
} 
the sector (see Ashta and Hudon, 2009, for a detailed discussion). Leaving ethical and mission-based considerations aside, this paper is the first, to our knowledge, to start from observable returns of publicly traded MFIs. From a portfolio perspective, these returns are to be judged not only on a case-by-case basis but also in regard to their correlations with other assets.

Previous work has already investigated the financial properties of microfinance investment. However, because of data availability issues, authors are bound to use figures extracted from annual accounting statements provided by the Microfinance Information Exchange (MIX) rather than high frequency market data. This significantly limits the relevance of their results for mainstream investors. From this perspective, Krauss and Walter (2009) present evidence that, over the period 1998-2006, including microfinance in global portfolios reduced overall portfolio volatility, but that the same result did not hold for domestic investors. Using MIX data for the period 1997-2007, Galema et al. (2011) apply the spanning test methodology proposed by De Roon et al. (2001), and confirm that investment in microfinance is beneficial in terms of portfolio diversification.

In this paper, we construct microfinance country equity indices and an international Global Microfinance Index (GMI). We analyze the changes in these indices, assessing in reference to comparable indices for the financial sector and also to national indices. Our findings show that microfinance has been closely correlated with the financial sector since 2003 . In terms of risk exposure, estimates of the Capital Asset Pricing Model (CAPM) demonstrate that microfinance shares exhibit higher market beta than those of conventional financial institutions and have equivalent currency exposure. 
The remainder of the paper is structured as follows. Section 1 describes the database and the methodology. In section 2, we study the joint movements of the finance and microfinance indices. In section 3, we estimate the CAPM including foreign exchange risk.. Section 4 concludes.

\section{Data and Methodology}

We consider the exhaustive universe of listed microfinance institutions. ${ }^{7}$ This approach is a real advance over the existing literature because the securities in question are the only assets that allow investors attracted by the microfinance sector to gain direct access to the capital of MFIs. The alternative, MIVs, concentrates primarily on types of loans to MFIs, and the choice of institutions benefiting from them is often unclear.

Three MFIs are quoted in South Africa: African Bank (the oldest quoted MFI, since January 1990), Blue Financial Services (BFS), and Capitec Bank; one in Kenya: Equity Bank; two in Indonesia: Bank Danamon (also one of pioneering quoted MFI, since April 1990) and Bank Rakyat Indonesia (BRI); one in Bangladesh: BRAC Bank; and two in Mexico: Banco Compartamos and Financiera Indepencia (FI).

$<$ Insert Table 1 here >

The market data (total return index and market capitalization) come from Datastream. The descriptive statistics for monthly returns are presented in Table 1 . They cover the period for

\footnotetext{
${ }^{7}$ We follow JP Morgan (2011) and consider the listed institutions with daily liquidity of at least USD 0.2 million. This ensures that prices are not distorted by supply/demand imbalances. Actually, we only exclude SKS, the Indian quoted MFI, because its IPO is too recent (August 2010)
} 
which each series is available in Datastream, and end in December 2010. These statistics show great disparity in returns from MFIs. Some institutions have been exceptionally profitable since from their IPO, such as African Bank (annualized monthly return of 57.9\% since 1990) and Capitec (71.8\% since 2002) in South Africa ${ }^{8}$ or Equity in Kenya ${ }^{9}$ (59.3\% since 2006). Conversely, others have performed disastrously, including BFS, a South African MFI, (-22.1\% since 2006). All have very high volatility (from $37.5 \%$ for Compartamos to 79.6\% for BFS) and high levels of extreme risks. Returns also display a phenomenon rarely found in finance: they are nearly always asymmetrical to the right, with skewness as high as 6.5 for African Bank. At the same time, African Bank has an exceptionally fat-tailed distribution, with kurtosis of 73.5 , and maximum of $266 \%$ for one month and $233 \%$ for one day, both occurring in February 1995. All MFI returns have been positively tested for stationarity.

To estimate the CAPM in section 3, we use country stock indices and a World index from Morgan Stanley Capital International (MSCI). More precisely, the country indices are quoted in domestic currencies and encompass 21 stocks in Mexico, 45 in South Africa, 22 in Indonesia, and 7 in Kenya. ${ }^{10}$ The World index (MSCI All Countries World Index) is quoted in USD and contains 9,000 stocks from both developed (24) and emerging (21) countries. The stock selection is based on liquidity (trade frequency and volume) and size (market value). The industry composition of each country index reflects the specific features of the local

\footnotetext{
${ }^{8}$ The history of the microfinance industry in South Africa is singular (see Porteous and Hazelhurst, 2004; Napier, 2006). After having experienced full deregulation in the post-apartheid period (1992-1999) which enhanced commercial microcredit activities, the sector started to be supervised by the Microfinance Regulatory Council (MFRC) which is "entrusted with the responsibility of regulating the activities of the micro lending sector and to protect consumers against deceptive and unfair lending practices in terms of the Usury Act Exemption Notice (...) of June 1999." (http://www.dti.gov.za/thedti/mfrc.htm).

${ }^{9}$ Rhyne (2009) mentions that Equity Bank boasts over a million small savers and was recognized as the best bank in Kenya by Euromoney in 2007.

${ }^{10}$ Bangladesh is excluded from the universe for CAPM estimations due to unavailability of interest rates.
} 
market. Data for interest rates (three-month interbank rates) in each country and exchange rates are from Datastream.

To compare monthly changes in microfinance and finance stocks in the five selected countries, we construct original capitalization-weighted indices for both the microfinance and the financial sectors. We proceed in the following way. First, for each country we create a local microfinance return index ${ }^{11}$ starting when at least one MFI is quoted in that country. For comparability, local indices are converted to USD at the current exchange rate. Second, we aggregate the local microfinance indices into the Global Microfinance Index (GMI) by weighting each stock by its market capitalization. The GMI is defined from January 1990 on. Between January and March 1990 the GMI comprises a single stock, African Bank (South Africa). Subsequent additions take place in April 1990 (Danamon, Indonesia), February 2002 (Capitec, South Africa) and November 2003 (Bank Rakyat, Indonesia). After 2005, microfinance IPOs accelerated and the GMI was adjusted more frequently. At the end of the sample period (December 2010), the GMI is composed of nine stocks from five countries with the following geographic weights: $63 \%$ for Indonesia, $18 \%$ for South Africa, $13 \%$ for Mexico, $4 \%$ for Kenya, and $1 \%$ for Bangladesh.

Figure 1 charts the movements in the local microfinance indices (in local currency), each normalized to 100 at its starting date. Importantly, the South African index experienced such exceptional growth over the period that a different scale is needed to represent its change (axis on the right side of Figure 1). Figure 1 also charts the change in the GMI (in USD). This graph should be interpreted with caution at the beginning of the sample period because of the lack of geographical diversification.

\footnotetext{
${ }^{11}$ The index takes into account reinvested dividends.
} 
< Insert Table 2 here >

Table 2 presents monthly descriptive statistics for all microfinance indices. Annualized profitability of national indices ranges from $11 \%$ for Indonesia since 1990 to $58.8 \%$ for Kenya (over a short period, since 2006). Owing to the diversification effect, national microfinance indices present lower dispersion than the MFIs themselves. However, because the indices remain weakly diversified, their volatilities are higher than those of traditional emerging indices (from $34.7 \%$ for Mexico to $78.1 \%$ for South Africa, compared with the equivalent MSCI emerging indices, for which volatility ranges from $20.6 \%$ for South Africa to $35.9 \%$ for Indonesia). Extreme risks are also much higher: skewness is highly positive (from 0.39 for Bangladesh to 6.59 for South Africa), as it is for individual MFIs (except for the Mexican index, where Compartamos is the only MFI to have left-skewed asymmetrical returns); and kurtosis is very high (up to 74.3 for South Africa) for national microfinance indices, except for Bangladesh and Mexico (which has kurtosis of nearly 3). The GMI index has an average annualized monthly return of $20.3 \%$ and volatility of $56 \%$, and more moderate extreme risks (skewness of 0.5 and kurtosis of 5.91).

For the finance sector, we construct local and global indices by mimicking the construction of the microfinance indices. More precisely, in each of the five countries under consideration, the local finance index is built from the financial stocks belonging to the corresponding MSCI universe, but excluding microfinance. Consequently, at the end of the sample period the local financial indices are composed of stocks from the following numbers of banking institutions: 5 in South Africa, 3 in Kenya, 3 in Indonesia, 11 in Bangladesh, and 2 in Mexico. Again, each index is weighted by market capitalization. The number of financial institutions in Bangladesh 
is striking. This is because the financial sector is particularly well developed compared with other sectors in that country (Demirgüc-Kunt and Levine, 1999). Bangladesh experienced a major financial sector reform, initiated by the World Bank at the beginning of the 1990's and pursued by the government after 1996, aimed at expanding and diversifying the sector and privatizing national banks (Uddin and Hopper, 2003).

The Global Finance Index (GFI) aggregates the five local indices. However, to allow rational comparisons with the GMI, the country weights in the GFI are constrained to be those of the GMI. Specifically, the weight of each country in both the GMI and the GFI is dictated by the size of its microfinance sector (converted to USD). Interestingly, on the Indonesian stock market the microfinance sector (present since 1990) predates the banking sector (present since 1996). As a result, the GFI can be defined only for the period starting in November 1996.

Figure 2 presents the changes in the local and global indices. Returns from the traditional financial indices present far lower dispersion than do the microfinance indices: average annualized monthly returns range from $22.5 \%$ for South Africa since 1990 and $33.5 \%$ for Kenya since 1991. However, financial indices' volatility (from $25.9 \%$ for South Africa to $51.6 \%$ for Indonesia) is much lower than for microfinance indices. These results also apply to the GFI index, whose average annualized monthly return $(22.5 \%)$ is slightly higher than that of the GMI index (20.3\%), and with lower volatility (47.5\% versus $56 \%$ ).

\section{Joint Movements of the Finance and Microfinance Global Indices}

To facilitate comparison of our two global indices, the GFI for finance and the GMI for microfinance, a common base was set at December 1996. The graph of daily cumulative 
returns of the GFI and GMI (Figure 3) shows that after a period of great disparity between finance and microfinance, with higher instability for microfinance, a phenomenon of convergence appeared. In fact, the correlation between the GMI and the GFI rose from 33\% over the first half of the sample period (until December 2003) to 79\% during the second half. Volatilities for the two series also differ by sub-period (initially $53 \%$ and then $30 \%$ for finance, and $76 \%$ and $34 \%$ for microfinance). The Engle and Sheppard (2001) test for constant conditional correlation confirms the instability of correlations at the $1 \%$ level. ${ }^{12}$

To describe the joint movements of the GFI and GMI indices, we adopt DCC-MVGARCH ${ }^{13}$ modeling (Engle and Sheppard, 2001; Engle, 2002), which enables us to factor in dynamic conditional correlations. This approach is often used to model correlation dynamics between financial series (Kearney and Poti, 2006; Brière and Signori, 2009). Consider daily returns, $r_{t}=\left(r_{1, t}, r_{2, t}, \ldots, r_{k, t}\right)^{\prime}$, of $k$ assets. Let us assume that these returns are conditionally normal ${ }^{14}$ with zero mean and conditional covariance matrix $H_{t}$ :

$$
r_{t} \mid I_{t} \sim N\left(0, H_{t}\right)
$$

Matrix $H_{t}$ can be decomposed as follows:

$$
H_{t}=D_{t} R_{t} D_{t}
$$

where $R_{t}$ is the conditional correlation matrix and $D_{t}=\left(\sqrt{h_{i t}}\right)$ is a $k^{*} k$ diagonal matrix of which $i$-th element is the conditional standard deviation of the return of asset $i$.

\footnotetext{
${ }^{12}$ We test the null hypothesis of constant correlation. The test statistic take value 36.47 (p-value = 0 ).

${ }_{13}^{13}$ Dynamic Conditional Correlation Multivariate Generalized Autoregressive Conditional Heteroskedasticity

${ }^{14}$ Without normality the results are still valid but with a Quasi Maximum Likelihood Estimation (QMLE) interpretation.
} 
A preliminary analysis (not reported there) has been conducted to optimally choose the orders of the univariate GARCH processes for GFI and GMI. As a result, the conditional variances are modeled using a GARCH $(1,1)$ specification of the form:

$$
\sigma_{i, t}^{2}=\omega_{i}+\alpha_{i} \varepsilon_{i, t-1}^{2}+\beta_{i} \sigma_{i, t-1}^{2}
$$

where $\omega_{i}, \alpha_{i}$ and $\beta_{i}$ are non-negative parameters satisfying $\alpha_{i}+\beta_{i}<1$, and the $\left(\varepsilon_{i, t}\right)$ 's are sequences of independent and identically distributed random variables, with mean 0 and variance 1.

The DCC model proposed by Engle (2002) involves two-stage estimation of the conditional covariance matrix $H_{t}$. In the first stage, univariate volatility models are fitted for each stock return and estimates of the $h_{i i, t}$ 's are obtained. In the second stage, stock-return residuals are normalized: $u_{i t}=\frac{\varepsilon_{i t}}{\sqrt{h_{i i, t}}}$.

In the DCC model, the $k \times k$ time-varying covariance matrix of $\left(u_{t}\right)$ denoted by $Q_{t}$ fulfils:

$$
Q_{t}=(1-A-B) E\left(u_{t} u_{t}^{\prime}\right)+A u_{t-1} u_{t-1}^{\prime}+B Q_{t-1}
$$

where $A$ and $B$ are non-negative parameters satisfying $A+B<1$. The proper correlation matrix $R_{t}$ is given by:

$$
R_{t}=\left(\operatorname{diag}\left(Q_{t}\right)\right)^{-1 / 2} Q_{t}\left(\operatorname{diag}\left(Q_{t}\right)\right)^{-1 / 2}
$$

We follow Engle's (2002) two-step log-likelihood estimation procedure for the DCC (results not reported here). Table 3 display the estimates of the univariate GARCH parameters $\left(\omega_{i}, \alpha_{i}\right.$, and $\left.\beta_{i}\right)$ and the DCC parameters $(A$ and $B)$. With reference to parameter significance 
and information criteria, the best model is unambiguously the GARCH $(1,1)$ for both series, which is also the most frequent specification for financial returns.

$<$ Insert Table 3 here >

The coefficients of the lagged variance and innovation terms are highly significant, which is consistent with time-varying volatility and appropriateness of the GARCH $(1,1)$ specification. Both $\operatorname{GARCH}(1,1)$ univariate processes present a high degree of persistence (long memory), signaled by $\alpha_{i}+\beta_{i}$ being close to 1 , which is even higher for GMI (0.996) than for GFI (0.986). Figure 4 plots the estimated conditional volatilities of both the GMI and GFI. Figure 5 plots their conditional correlation.

The volatility of both indices has fallen significantly since the early 2000's. The decline occurred earlier for finance (starting in 2000) than for microfinance (starting in 2002). The rise in conditional correlation between the two sectors is very pronounced over the study period. It occurred mainly between 2003 and 2006, when correlations changed from being highly variable (between $-20 \%$ and $70 \%$ ) to much more stable (around $80 \%$ ). Although the 2000-2001 crisis had little effect on microfinance equities, ${ }^{15}$ they were affected by the 20072008 crisis, confirming that microfinance is no longer a crisis-resilient sector (Visconti, 2008; Wagner, 2010).

In conclusion, the microfinance sector has been trending towards gradual integration into mainstream finance. However, it has retained certain specific traits. Microfinance tends to develop in countries where the financial sector is relatively weak (Vanroose and D'Espallier,

\footnotetext{
${ }^{15}$ Patten et al. (2001) also exhibit the good performances of BRI during the East Asian crisis.
} 
2009; Maksudova, 2010), ${ }^{16}$ such that the regional distribution of listed MFIs differs from that of the traditional financial sector. From this point, although the two sectors are converging, the potential for microfinance to provide diversification in an equity portfolio can be distinguished from the diversification potential of finance by regional bias. Section 3 considers the nature of risks assumed by domestic and international investors in finance and microfinance equities.

\section{Risk Factors of Microfinance Investment}

The profitability of the microfinance sector is hotly debated. ${ }^{17}$ For instance, Cull et al. (2009) state that: "The evidence suggests that investors seeking pure profits would have little interest in most of the institutions that are now serving poorer customers" (p. 169). Schmidt (2010) is even more pessimistic about the potential for profitable investment in microfinance: “(...) I fear that the high expectations regarding the return on an investment in MFIs, which I consider to be exaggerated, will have a negative impact on activities in the microfinance sector (...)" (p. 125). ${ }^{18}$ In this section, we revisit this issue by investigating the sensitivity of both microfinance and finance stock returns to market and foreign-exchange risks. As shown by Solnik (1974) and Adler and Dumas (1983), foreign exchange risk plays a key role in international asset pricing. Moreover, Crabb (2004) stresses that foreign exchange remains an important source of risk for MFIs that are exposed to the devaluation of their funding sources.

\footnotetext{
${ }^{16}$ However, Hermes et al. (2009) note that MFIs are more efficient in countries with more highly developed financial sectors. Besides, barriers to banking activity largely vary across countries (Beck et al., 2008).

${ }^{17}$ Caudill et al. (2009) show on data from Eastern Europe and Central Asia that larger MFIs offering deposits are the most cost effective.

${ }^{18}$ Other opinions are more favorable. For instance, Dieckmann, (2007) says: "Apart from poverty alleviation, microfinance offers stable financial returns over the economic cycle, low loan portfolio default rates and potentially low correlations to mainstream capital markets" (p.19)
} 
Two perspectives are analyzed in turn. First, we consider the situation of a domestic investor in a country where microfinance equity is available. Second, we consider an international investor contemplating sector-wise investment in finance and microfinance indices.

To address the domestic investor's situation, we follow Harvey (1995) and estimate a CAPMtype model in local currency including two factors: a standard market factor and a foreign exchange factor. ${ }^{19}$ Owing to the unavailability of interest rate data for Bangladesh, the following model is estimated for four countries (Indonesia, Kenya, Mexico, and South Africa):

$$
\begin{aligned}
& \left(R_{M I}^{k}-r_{f}^{k}\right)=\alpha_{1}+\beta_{1}\left(R_{M}^{k}-r_{f}^{k}\right)+\gamma_{1} R_{F X}^{k}+\varepsilon_{t} \\
& \left(R_{F I}^{k}-r_{f}^{k}\right)=\alpha_{1}+\beta_{1}\left(R_{M}^{k}-r_{f}^{k}\right)+\gamma_{1} R_{F X}^{k}+\varepsilon_{t}
\end{aligned}
$$

where $R_{M I}^{k}$ is the monthly return of the microfinance index of country $k$ in domestic currency, $R_{F I}^{k}$ is the return on the financial index of country $k$ in domestic currency, $R_{M}^{k}$ is the return on the domestic market (MSCI index), $r_{f}^{k}$ is the country's risk-free rate, and $R_{F X}^{k}$ is the exchange rate return (USD versus domestic currency). ${ }^{20}$

To address the international investor's situation, we estimate the basic CAPM specification with a single market factor proxied by the return of the MSCI All Countries World index:

$$
\begin{aligned}
& \left(R_{G M I}-r_{f}\right)=\alpha_{2}+\beta_{2}\left(R_{M}-r_{f}\right)+\varepsilon_{t} \\
& \left(R_{G F I}-r_{f}\right)=\alpha_{2}+\beta_{2}\left(R_{M}-r_{f}\right)+\varepsilon_{t}
\end{aligned}
$$

\footnotetext{
${ }^{19}$ However, we use pure foreign exchange exposure against the USD rather than a trade-weighted index of currency returns, because banks and microfinance institutions primarily have liabilities in USD.

${ }^{20}$ Certains pays étudiés ont été soumis à des contrôles de capitaux visant à restreindre les flux entrants de capitaux, comme par exemple l'Indonésie depuis juin 2010. Pour le reste, les devises considérées s'échangent librement sur le marché, ce qui confère du réalisme à notre approche.
} 
where $R_{G M I}$ is the monthly return of the GMI index, $R_{G F I}$ is the monthly return of the GFI financial index, $R_{M}$ is the return of the MSCI All Countries World index, and $r_{f}$ is the US risk-free rate. All returns are calculated using prices in USD.

< Insert Table 4 here >

The upper part of Table 4 presents the estimation results for the country-specific regressions given by equations (1) and (2), and the outcomes of Wald tests for equality of the beta coefficients between finance and microfinance. Except for South African microfinance, the intercepts are not significantly different from zero. The loadings on the domestic market factors are all significant, both for microfinance and finance stocks, lying between 0.72 (Indonesia) and 1.55 (Kenya) for microfinance, and between 0.53 (Mexico) and 1.01 (Kenya) for finance. In general, market betas are higher for microfinance than for finance, signaling a higher systematic risk for MFIs than for traditional banks. However, the difference is hardly significant. The only exception is Indonesia, where microfinance exhibits a smaller market beta (0.72) than finance $(0.95)$, the difference being significant at the $10 \%$ level. For all countries, R-squared values are relatively low (between 19\% for South African microfinance and $55 \%$ for Indonesian finance), which is a typical feature of market beta estimation (Harvey, 1995). ${ }^{21}$

Exposure to the currency factor produces the intuitively expected result: betas are negative and significant for both finance and microfinance, except for Kenya, where betas are not significant. Banks and MFIs often fund their portfolios through debt in foreign currency,

\footnotetext{
${ }^{21}$ Indeed, CAPM is a parsimonious model, and additional local factors would likely be needed to further explain the returns of the finance and microfinance stocks.
} 
especially USD (Crabb, 2004). When the dollar appreciates, financing becomes more expensive but the institutions' revenues (from repayment of loans contracted in local currency) remain fixed, thus penalizing them. Only a few MFIs are not exposed to foreign exchange risk, either because they operate in a fully dollarized economy, or because they solely trade in local currency. Interestingly, foreign exchange betas are not significantly different for the finance and microfinance sectors, meaning that the two types of institution share similar exposures.

The lower part of Table 4 provides the estimation results for equations (3) and (4). As a robustness check, we estimate the CAPM for the two global indices, GFI and GMI, firstly on the full sample period (1996-2010) and secondly on two equally split sub-samples (1996-2003 and 2003-2010). The results reveal that market betas are higher than one for both microfinance and finance. This likely reflects the higher systematic risk of equity from emerging countries compared with a well-diversified world portfolio balanced between emerging- and developed-market stocks. Market betas are higher for microfinance than for finance on the full sample period (1.63 versus 1.35) as well as on the two sub-samples $(1.67$ versus 1.31 before 2003, 1.59 versus 1.38 after 2003). Remarkably, the betas over the two sub-periods take quite similar values, making our results robust. However, the Wald test rejects the equality between the betas of the finance and microfinance sectors, on both the full period and more recent periods. While this outcome might seem puzzling given the convergence observed in the previous section, it might result from differences in country effects. This intuition is corroborated by local regressions. Indeed, the betas of the two sectors are not significantly different for South Africa and Kenya, and only borderline significantly different (at the 10\% level) for Indonesia and Mexico. 
Summing up, both the finance and the microfinance sectors exhibit high market betas, locally and globally. Moreover, domestic investors in both sectors are significantly exposed to foreign exchange risk. Lastly, that microfinance is converging towards mainstream finance is confirmed by the proximity of their market and foreign exchange betas in domestic markets.

\section{Conclusion}

Despite the impressive development of the microfinance sector, the financial performance of microfinance equity is poorly understood. This is probably due to data availability issues. Although suffering from data limitations, this paper takes full advantage of daily quoted prices of microfinance stocks from their issuance, and draws a global picture of worldwide microfinance equity. Two main messages stand out. First, we have demonstrated that the microfinance sector had largely converged on the mainstream financial sector by around 2003. This is consistent with the evidence that the MFIs that issue stocks are the ones that behave most like banks without really intending to serve the poorest of the poor (Cull et al., 2007). Second, we have looked into the impacts of market and foreign-exchange risk factors on both finance and microfinance stocks, locally and globally. Although the situation is far from homogenous across countries, the picture that emerges is consistent with the convergence outcome. Moreover, we have confirmed the intuition that both sectors are highly exposed to exchange rate risk, probably because they obtain most of their funding from international capital markets.

A seminal contribution in many respects, this paper also suffers from econometric drawbacks. The main problem likely relates to the underlying probability distributions of the returns. As the descriptive statistics have amply shown, we are dealing with series that depart 
significantly not only from normality, a common feature of most financial series, but also from the typical heavy-tail distributions that financial econometricians are used to dealing with. Moreover, CAPM-style regressions are known to miss important risk factors (Cochrane, 1999), which we were unable to incorporate for at least two reasons: the lack of data on such factors for developing countries, and the limited length of the available price series. We therefore view our empirical results as challenging but still preliminary, and we hope they will motivate further studies in the field. Indeed, the quoted microfinance sector is still in its infancy, and understanding of its performance drivers is likely to increase with time.

Lastly, emerging financial markets have been documented as a key source of diversification for Western portfolio holders (Bekaert and Harvey, 2003; Quisenberry and Griffith, 2010). However, the optimal composition of portfolios made up of emerging-country stocks remains largely unexplored, especially with respect to their sensitivity to global crises. In this respect, one promising avenue for research is the way sector-specific and/or country-specific investments could help robustify global portfolios (Brière and Szafarz, 2008; Brière et al., 2010). For this, adequate sector delineation is a prerequisite. Our paper has also taken steps in that direction. 


\section{References}

Adler M. and B. Dumas (1983), "International portfolio selection and corporation finance: A synthesis", Journal of Finance 38, 925-984.

Armendariz, B. and A. Szafarz (2011), “On mission drift in microfinance institutions”, in B. Armendariz and M. Labie (Eds.), The Handbook of Microfinance, London-Singapore: World Scientific Publishing, 341-366.

Ashta, A. and M. Hudon (2009), “To whom should we be fair? Ethical issues in balancing stakeholder interests from Banco Compartamos case study”, CEB Working Paper No. 09/036, Université Libre de Bruxelles.

Beck T., A. Demirgüç-Kunt, and M.S. Martinez Peria (2008), "Banking services for everyone? Barriers to bank access and use around the world", World Bank Economic Review 22 (3), 397-430.

Bekaert G. and C.R. Harvey (2003), "Emerging markets finance”, Journal of Empirical Finance 10 (1-2), 3-55.

Brière M., A. Burgues, and O. Signori (2010), "Volatility exposure for strategic asset allocation”, Journal of Portfolio Management 36 (3), 105-116.

Brière M., and O. Signori (2009), "Do inflation-linked bonds still diversify?", European Financial Management, 15, 279-297.

Brière M., and A. Szafarz (2008), “Crisis-robust bond portfolios”, Journal of Fixed Income 18 (2), 57-70. 
Caudill, S.B., D.M. Gropper, and V. Hartaska (2009), "Which microfinance institutions are becoming more cost effective with time? Evidence from a mixture model", Journal of Money, Credit and Banking 41 (4), 651-672.

Cochrane, J.H. (1999), "Portfolio advice for a multifactor world", Economic Perspectives 23 (3), 59-78.

Copestake, J. (2007), “Mainstreaming microfinance: Social performance management or mission drift? ", World Development 35 (10), 1721-1738.

Crabb P.R. (2004), "Foreign exchange risk management practices of microfinance institutions", Journal of Microfinance 6 (2), 51-63.

Cull, R., A. Demirgüç-Kunt, and J. Morduch (2007), "Financial performance and outreach: a global analysis of leading microbanks", Economic Journal 117 (517), F107-F133.

Cull, R., A. Demirgüç-Kunt, and J. Morduch (2009), "Microfinance meets the market", Journal of Economic Perspectives 23 (1), 167-192.

Demirgüç-Kunt, A. and R. Levine (2001), "Bank-based and market-based financial systems: Cross country comparison”, World Bank Policy Research Working Paper, 1999.

De Roon, F.A., T.E. Nijman, and B.J.M. Werker (2001), “Testing for mean-variance spanning with short sales constraints and transaction costs: The case of emerging markets", Journal of Finance 56 (2), 721-742.

Di Bella G. (2011), “The impact of the global financial crisis on microfinance and policy implications", IMF Working Paper 11-175.

Dieckmann, R. (2007), “Microfinance: An emerging investment opportunity”, Deutsche Bank Research, December. 
Dorfleitner, G., M. Leidl, and J. Reeder (2011), “Theory of social returns in portfolio choice with application to microfinance", University of Regensburg working papers in business, economics and management information systems, 455.

Drut B. (2010), "Social responsibility and mean-variance portfolio selection", Economix Working Paper, 2010-03, Université de Paris Ouest-Nanterre.

Engle, R.F. (2002), "Dynamic Conditional Correlation - A simple class of multivariate GARCH models", Journal of Business and Economics Statistics 20 (3), 339-350.

Engle, R.F. and Sheppard, K. (2001), “Theoretical and empirical properties of dynamic conditional correlation multivariate GARCH," University of California, San Diego, Department of Economics Discussion Paper, 2001-15.

Galema, R., R. Lensink, and L. Spierdijk (2011), "International diversification and microfinance", Journal of International Money and Finance 30 (3), 507-515.

Gonzalez A. (2007), "Resilience of microfinance institutions to national macroeconomic events: An econometric analysis of MFI asset quality", Microfinance Information Exchange Discussion Paper, 1.

Ghosh S. and E. Van Tassel (2008), “A model of mission drift in microfinance institutions”, Department of Economics, Florida Atlantic University, December.

Harvey C.R. (1995), “The risk exposure of emerging equity markets”, World Bank Economic Review 9 (1), 19-50.

Hermes, N., R. Lensink, and A. Meesters (2009), "Financial development and the efficiency of microfinance institutions", Available at SSRN: http://ssrn.com/abstract=1396202.

Hudon, M. (2010), "Subsidies and financial performances of the microfinance institutions: Does management matter?," Journal of International Development 22 (7), 890-905. 
Hudon, M. and D. Traca, (2011), "On the efficiency effects of subsidies in microfinance: An empirical inquiry," World Development 39 (6), 966-973.

J.P. Morgan (2009), "Microfinance: Shedding Light on Microfinance Equity Valuation: Past and Present", J.P. Morgan Global Research, in collaboration with CGAP, February.

J.P. Morgan (2011), “Discovering Limits: Global Microfinance Valuation Survey 2011”, J.P. Morgan Global Research, in collaboration with CGAP, July.

Kearney C. and V. Potì (2006), "Correlation dynamics in European equity markets", Research in International Business and Finance 20 (3), 305-321.

Krauss, N.A. and I. Walter (2009), “Can microfinance reduce portfolio volatility?”, Economic Development and Cultural Change 58 (1), 85-110.

Maksudova, N. (2010), "Contribution of microfinance to financial sector development and growth", CERGE-EI, Charles University, Prague.

Matthäus-Maier, I. and J. von Pischke (Eds.) (2006), Microfinance Investment Funds, Berlin: Springer.

McIntosh C. and B. Wydick (2005), "Competition and microfinance", Journal of Development Economics 78 (2), 271-298.

Mersland R. (2009), "The cost of ownership in microfinance organizations", World Development 37 (2), 469-478.

Mersland R. and T. Strøm (2010), “Microfinance mission drift?”, World Development 38 (1), 28-36.

Napier, M. (2006), "Provision of financial services in South Africa" in OECD Trade Policy Studies, Liberalisation and Universal Access to Basic Services, Paris: OECD Publishing, 197-213. 
Nawaz, A. (2010), "Efficiency and productivity of microfinance: Incorporating the role of subsidies," CEB Working Paper CEB 10/009, Université Libre de Bruxelles.

Patten, R.H., J.K. Rosengard and D. E. Johnston Jr (2001), “Microfinance success amidst macroeconomic failure: The experience of Bank Rakyat Indonesia during the East Asian crisis," World Development 29 (6), 1057-1069.

Porteous, D. and E. Hazelhurst (2004), Banking on Change: Democratising Finance In South Africa, 1994-2004 and Beyond, Cape Town: Double Storey.

Quisenberry C. and B. Griffith (2010), "Frontier equity markets: A primer on the next generation of emerging markets", Journal of Wealth Management 13 (3), 50-58.

Rhyne, E. (2009), Microfinance for Bankers and Investors, US: McGraw-Hill.

Schmidt, R.H. (2010), "Microfinance, commercialization and ethics", Poverty \& Public Policy 2 (1), 99-137.

Solnik B.H. (1974), “An equilibrium model of the international capital market”, Journal of Economic Theory 8 (4), 500-524.

Uddin S. and T. Hopper (2003), “Accounting for privatisation in Bangladesh: Testing World Bank claims", Critical Perspectives on Accounting 14 (7), 739-774.

Vanroose, A. and B. D’Espallier (2009), "Microfinance and financial sector development", CEB Working Paper CEB 09040, Université Libre de Bruxelles.

Visconti, R.M. (2008), “Are microfinance institutions in developing countries a safe harbour against the contagion of global recession?", in J.J. Choi and M.G. Papaioannou (Eds.), Credit, Currency or Derivatives: Instruments of Global Financial Stability of Crisis?, 389438. 
Wagner, C. (2010), "From boom to bust: How different has microfinance been from traditional banking?", Frankfurt School Working Paper $N^{\circ} 156$. 


\section{Tables}

Table 1: Descriptive statistics of microfinance stocks: market capitalization and monthly returns in local currency

\begin{tabular}{|c|c|c|c|c|c|c|c|c|c|}
\hline & African Bank & Capitec & BFS & Equity & Danamon & BRI & BRAC & Compartamos & $\mathrm{FI}$ \\
\hline Country & South Africa & South Africa & South Africa & Kenya & Indonesia & Indonesia & Bangladesh & Mexico & Mexico \\
\hline Market Capitalization & 3983.3 & 1763.1 & 22.89 & 1168.57 & 5995.85 & 14199.43 & 324.05 & 3556.38 & 685.55 \\
\hline Ann. Mean & $57.86 \%$ & $71.80 \%$ & $-22.06 \%$ & $59.28 \%$ & $8.93 \%$ & $44.80 \%$ & $42.79 \%$ & $25.56 \%$ & $-2.52 \%$ \\
\hline Median & $2.07 \%$ & $4.56 \%$ & $-2.34 \%$ & $3.67 \%$ & $0.00 \%$ & $3.55 \%$ & $3.99 \%$ & $1.16 \%$ & $-1.37 \%$ \\
\hline Max & $266.67 \%$ & $94.73 \%$ & $85.61 \%$ & $62.47 \%$ & $100.05 \%$ & $38.10 \%$ & $37.39 \%$ & $28.31 \%$ & $29.59 \%$ \\
\hline Min & $-49.20 \%$ & $-19.20 \%$ & $-60.84 \%$ & $-27.57 \%$ & $-54.37 \%$ & $-36.11 \%$ & $-22.73 \%$ & $-28.76 \%$ & $-22.85 \%$ \\
\hline Volatility & $78.48 \%$ & $47.47 \%$ & $79.62 \%$ & $65.59 \%$ & $63.10 \%$ & $40.71 \%$ & $48.02 \%$ & $37.57 \%$ & $43.21 \%$ \\
\hline Skewness & 6.50 & 2.66 & 0.73 & 1.04 & 0.96 & 0.02 & 0.39 & -0.01 & 0.46 \\
\hline Kurtosis & 73.50 & 18.09 & 6.40 & 4.73 & 8.21 & 4.20 & 2.89 & 3.57 & 2.88 \\
\hline Jarque-Bera & $53739.15^{\star \star \star}$ & $1130.49^{\star \star *}$ & $28.62^{\star \star \star}$ & $15.80^{\star \star \star}$ & $318.91^{\star \star \star}$ & $5.08^{\star}$ & 1.24 & 0.60 & 1.34 \\
\hline Dickey-Fuller & $-15.27^{\star \star \star}$ & $-12.27^{\star \star \star}$ & $-3.18^{\star *}$ & $-9.04^{* * *}$ & $-13.55^{\star * \star}$ & $-9.62^{\star \star \star}$ & $-5.25^{\star \star *}$ & $-4.79^{\star * *}$ & $-3.94^{* * *}$ \\
\hline Start date & Jan-90 & Feb-02 & Oct-06 & Aug-06 & Apr-90 & Nov-03 & Jan-07 & Apr-07 & Nov-07 \\
\hline End date & Dec-10 & Dec-10 & Dec-10 & Dec-10 & Dec-10 & Dec-10 & Dec-10 & Dec-10 & Dec-10 \\
\hline
\end{tabular}

* Significant at the $10 \%$ level.

** Significant at the $5 \%$ level.

*** Significant at the $1 \%$ level.

Note: Market capitalizations are given in millions of USD at the end of sample period (Dec. 31, 2010). The table reports summary statistics of monthly returns over the entire sample for which a series is available. Start and end dates are given in the last two rows. Jarque-Bera tests for normality of the returns' distribution, Dickey-Fuller tests for the presence of unit root in the time series.

Source: Authors' calculations.

Table 2: Descriptive statistics for the microfinance national indices and the Global Microfinance Index (GMI)

\begin{tabular}{|c|c|c|c|c|c|c|}
\hline & South Africa & Kenya & Indonesia & Bangladesh & Mexico & GMI \\
\hline Ann. Mean & $58.80 \%$ & $59.28 \%$ & $10.99 \%$ & $42.79 \%$ & $16.12 \%$ & $20.35 \%$ \\
\hline Median & $1.87 \%$ & $3.67 \%$ & $0.00 \%$ & $3.99 \%$ & $1.38 \%$ & $-0.03 \%$ \\
\hline Max & $266.67 \%$ & $62.47 \%$ & $100.05 \%$ & $37.39 \%$ & $25.93 \%$ & $71.08 \%$ \\
\hline Min & $-49.20 \%$ & $-27.57 \%$ & $-54.37 \%$ & $-22.73 \%$ & $-25.07 \%$ & $-49.93 \%$ \\
\hline Volatility & $78.10 \%$ & $65.59 \%$ & $61.96 \%$ & $48.02 \%$ & $34.68 \%$ & $55.99 \%$ \\
\hline Skewness & 6.59 & 1.04 & 1.03 & 0.39 & -0.08 & 0.50 \\
\hline Kurtosis & 74.83 & 4.73 & 8.65 & 2.89 & 3.03 & 5.91 \\
\hline Jarque-Bera & $55774.33^{\star * *}$ & $15.80^{* * *}$ & $373.78^{* * *}$ & 1.24 & 0.05 & $98.97^{\star * *}$ \\
\hline Dickey-Fuller & $-15.23^{\star * *}$ & $-9.04^{* * *}$ & $-13.58^{* * *}$ & $-5.25^{\star \star *}$ & $-4.30^{* * *}$ & $-13.75^{\text {***}}$ \\
\hline Start date & Jan-90 & Aug-06 & Apr-90 & Jan-07 & Apr-07 & Jan-90 \\
\hline End date & Dec-10 & Dec-10 & Dec-10 & Dec-10 & Dec-10 & Dec-10 \\
\hline
\end{tabular}

* Significant at the $10 \%$ level.

** Significant at the $5 \%$ level.

*** Significant at the $1 \%$ level.

Note: The table reports summary statistics of monthly returns over the entire sample for which a series is available. Start and end dates are given in the last two rows. National indices are in local currency, GMI (Global Microfinance Index) is in USD. Jarque-Bera tests for normality of the returns' distribution, Dickey-Fuller tests for the presence of unit root in the time series.

Source: Authors' calculations. 
Table 3: Estimates of univariate GARCH model, $\sigma_{i, t}^{2}=\omega_{i}+\alpha_{i} \varepsilon_{i, t-1}^{2}+\beta_{i} \sigma_{i, t-1}^{2}$, and DCC (1,1) model, $Q_{t}=(1-A-B) E\left(u_{t} u_{t}^{\prime}\right)+A u_{t-1} u_{t-1}^{\prime}+B Q_{t-1}$

December 1996 - December 2010

\begin{tabular}{|c|c|c|c|c|c|c|}
\hline Index & $\omega$ & $\alpha$ & $\beta$ & $\alpha+\beta$ & $A$ & $B$ \\
\hline GFI & $\begin{array}{l}1.07 \mathrm{E}-5^{\star * \star} \\
(1.21 \mathrm{E}-11)\end{array}$ & $\begin{array}{l}0.101^{\star \star \star} \\
(3.80 \mathrm{E}-4)\end{array}$ & $\begin{array}{c}0.884^{* * *} \\
(0.00048)\end{array}$ & 0.986 & - & - \\
\hline GMI & $\begin{array}{l}6.94 \mathrm{E}-6^{\star \star *} \\
(7.10 \mathrm{E}-12)\end{array}$ & $\begin{array}{c}0.077^{\star \star \star} \\
(2.25 \mathrm{E}-4)\end{array}$ & $\begin{array}{c}0.92^{* * *} \\
(2.28 \mathrm{E}-4)\end{array}$ & 0.996 & - & - \\
\hline GFI/GMI & - & $\begin{array}{l}- \\
-\end{array}$ & $\begin{array}{l}- \\
-\end{array}$ & $\begin{array}{l}- \\
-\end{array}$ & $\begin{array}{c}0.028^{\star * *} \\
(4.52 \mathrm{E}-05)\end{array}$ & $\begin{array}{c}0.028^{* * *} \\
(5.00 \mathrm{E}-05)\end{array}$ \\
\hline
\end{tabular}

* Significant at the $10 \%$ level.

** Significant at the 5\% level.

*** Significant at the $1 \%$ level.

Source: Authors' calculations.

Table 4: CAPM regressions

\begin{tabular}{|c|c|c|c|c|c|c|c|c|}
\hline & start date & end date & $\alpha$ & $\beta \quad$ Market & Wald Test & $\beta_{F X}$ & Wald Test & $R^{2}$ \\
\hline South Africa microfinance & Apr-97 & Dec-10 & $0.02^{\star \star \star}(2.19)$ & $0.90^{\star \star \star}(5.80)$ & $0.45(0.49)$ & $-0.36^{\star \star}(-1.82)$ & $0.08(0.78)$ & $20.17 \%$ \\
\hline South Africa finance & Apr-97 & Dec-10 & $0.00(0.88)$ & $0.81^{\star \star *}(11.66)$ & & $-0.39^{* * *}(-4.40)$ & & $51.7 \%$ \\
\hline Kenya microfinance & Aug-06 & Dec-10 & $0.03^{*}(1.59)$ & $1.55^{\star \star \star}(5.55)$ & $2.57(0.11)$ & $0.95(1.23)$ & $1.06(0.31)$ & $39.6 \%$ \\
\hline Kenya finance & Aug-06 & Dec-10 & $0.02(1.26)$ & $1.01^{\star * \star}(4.64)$ & & $0.01(0.02)$ & & $34.5 \%$ \\
\hline Indonesia microfinance & Nov-96 & Dec-10 & $-0.00(-0.42)$ & $0.72^{\star \star \star}(6.40)$ & $3.22^{*}(0.07)$ & $-0.39^{\star * \star}(-3.12)$ & $0.49(0.48)$ & $24.8 \%$ \\
\hline Indonesia finance & Nov-96 & Dec-10 & $0.00(0.68)$ & $0.95^{\star \star \star}(13.46)$ & & $-0.3^{\star \star *}(-3.85)$ & & $55.5 \%$ \\
\hline Mexico microfinance & Apr-07 & Dec-10 & $0.00(0.42)$ & $1.07^{\star * *}(4.65)$ & $3.45^{\star}(0.07)$ & $-0.07(-0.19)$ & $1.00(0.32)$ & $50.7 \%$ \\
\hline Mexico finance & Apr-07 & Dec-10 & $0.01^{*}(1.34)$ & $0.53^{\star \star \star}(3.02)$ & & $-0.58^{\star *}(-2.00)$ & & $48.9 \%$ \\
\hline GMI & Dec-96 & Dec-10 & $0.01(0.87)$ & $1.63^{\star \star \star}(7.76)$ & $18.96^{\star \star \star}(0.00)$ & - & - & $26.5 \%$ \\
\hline GFI & Dec-96 & Dec-10 & $0.01(1.26)$ & $1.35^{\star \star \star}(7.29)$ & & - & & $24.1 \%$ \\
\hline GMI & Dec-96 & Nov-03 & $-0.00(-0.15)$ & $1.67^{\star \star \star}(4.08)$ & $0.05(0.82)$ & - & - & $16.9 \%$ \\
\hline GFI & Dec-96 & Nov-03 & $0.01(0.39)$ & $1.31^{* \star *}(3.64)$ & & - & & $13.9 \%$ \\
\hline GMI & Dec-03 & Dec-10 & $0.02^{\star \star \star}(2.73)$ & $1.59^{\star \star \star}(10.49)$ & $29.67^{* \star *}(0.00)$ & - & - & $57.0 \%$ \\
\hline GFI & Dec-03 & Dec-10 & $0.021^{* * *}(2.36)$ & $1.38^{\star * *}(10.23)$ & & - & & $55.8 \%$ \\
\hline
\end{tabular}

* Significant at the $10 \%$ level.

** Significant at the 5\% level.

*** Significant at the $1 \%$ level

Note: The table reports regression estimates and t-statistics in parentheses. For Wald tests, the table displays $\mathrm{F}$ statistics and p-values in parentheses. GMI stands for Global Microfiinance Index, GFI for Global Finance Index.

Source: Authors' calculations. 


\section{Figures}

Figure 1: National microfinance indices in local currencies, monthly cumulative returns, January 1990 - December 2010

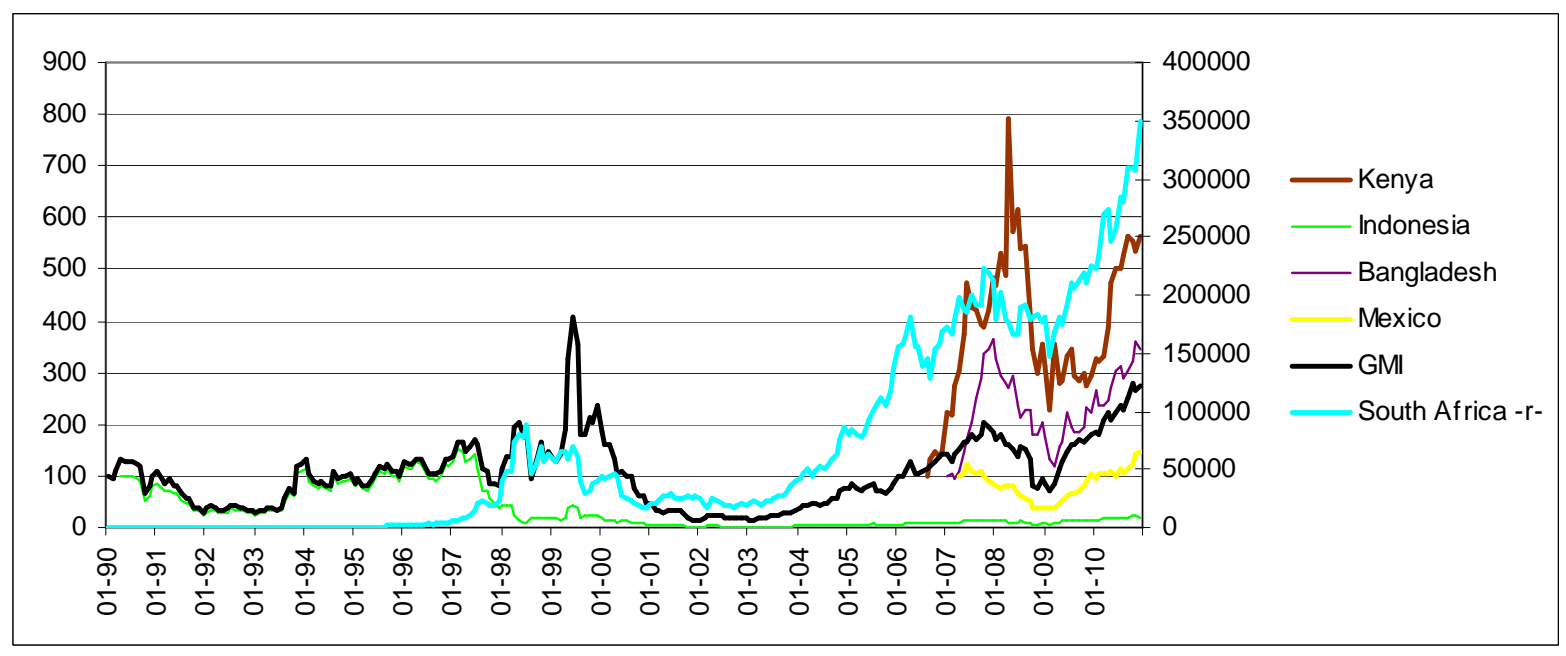

Note: -r- indicates that the series is displayed on the right axis.

Source: Authors' calculations.

Figure 2: National finance indices in local currencies, monthly cumulative returns, January 1990- December 2010

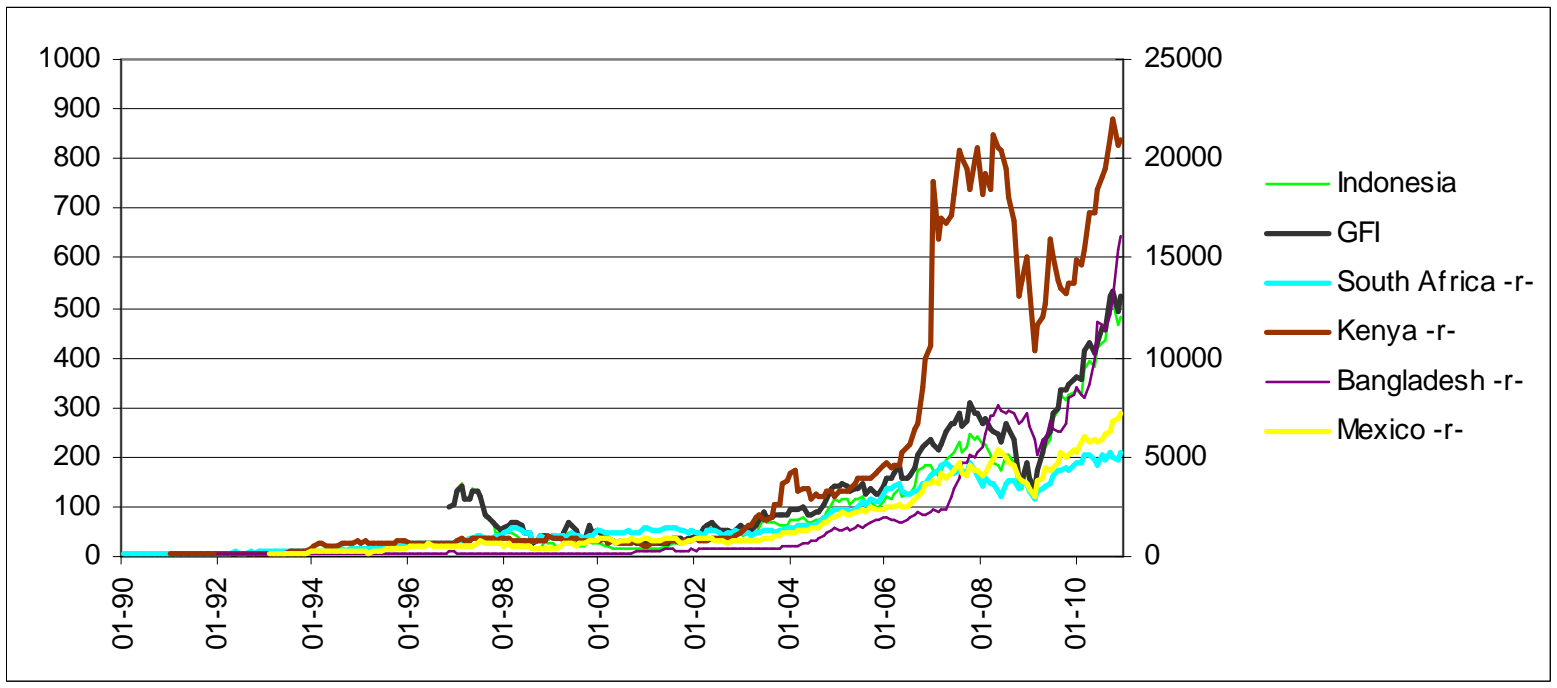

Note: -r- indicates that the series is displayed on the right axis. Source: Authors' calculations. 
Figure 3: Global Microfinance Index (GMI) and Global Financial Index (GFI), daily cumulative returns, December 1996 - December 2010

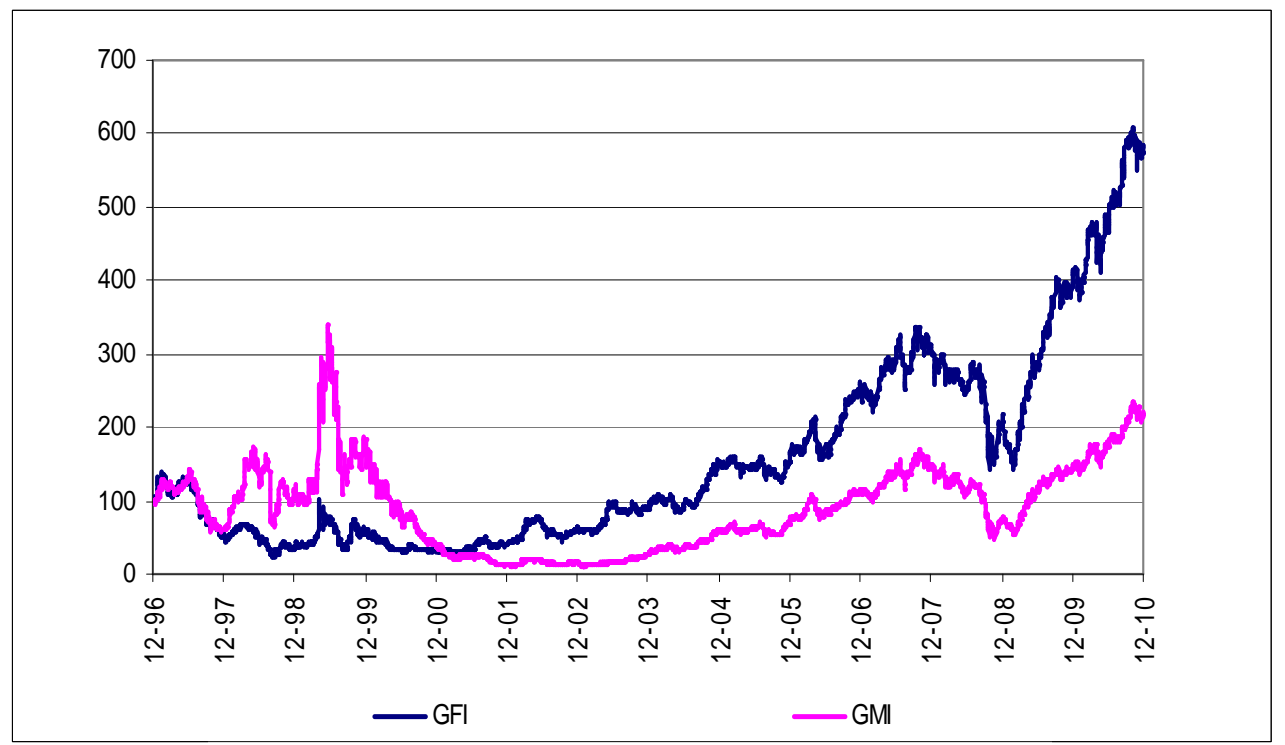

Source: Authors' calculations.

Figure 4: Conditional volatilities of the Global Microfinance Index (GMI) and the Global Financial Index (GFI), December 1996 - December 2010

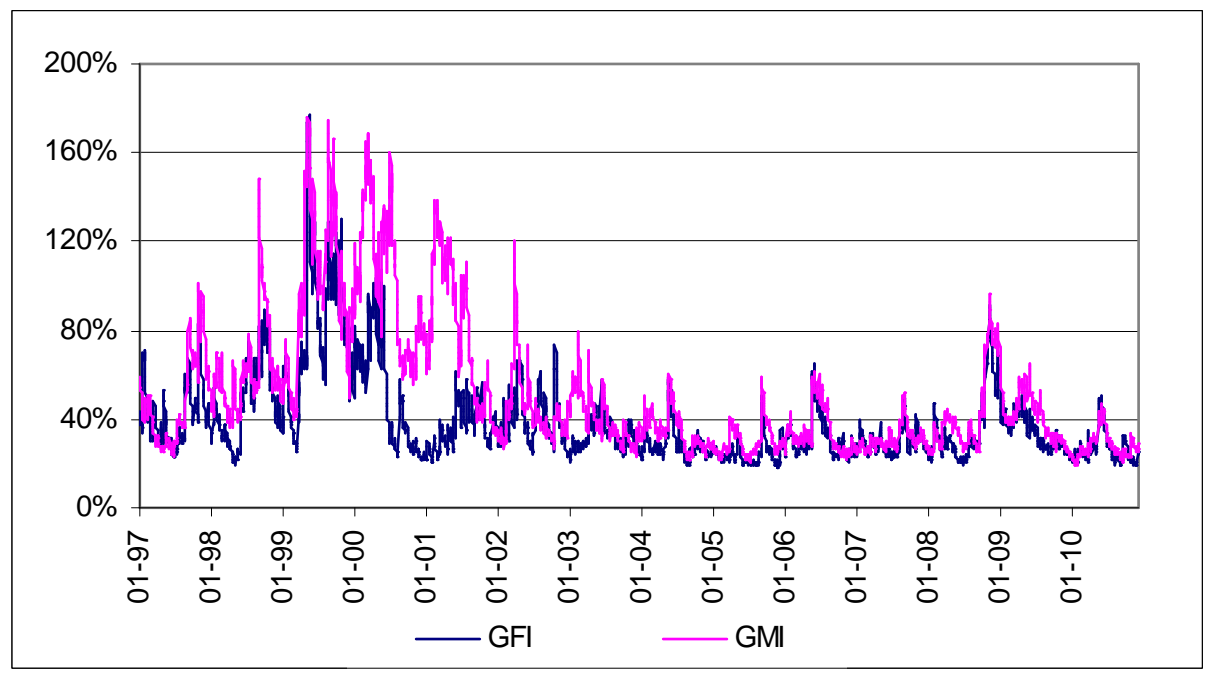

Source: Authors' calculations. 
Figure 5: Conditional correlation between the Global Microfinance Index (GMI) and the Global Financial Index (GFI), December 1996 - December 2010

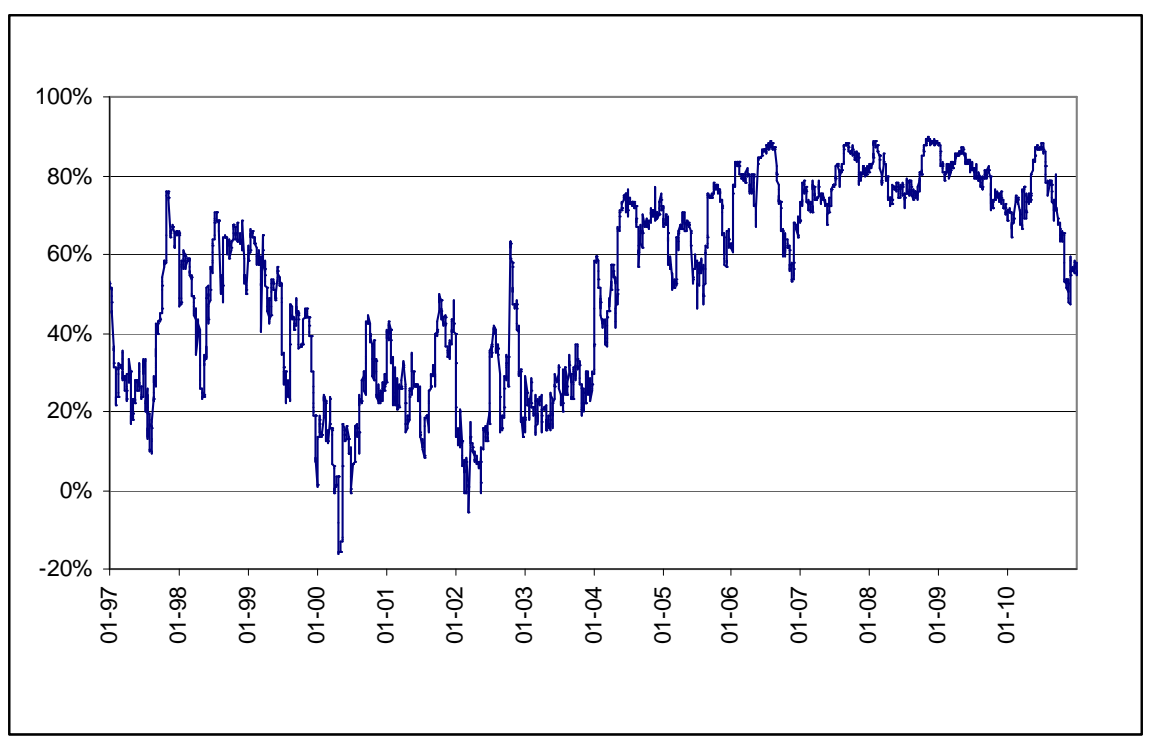

Source: Authors' calculations. 